\title{
ANALISIS PENGARUH JUMLAH KREDIT, LOAN TO ASSET RATIO (LAR), DAN LOAN TO DEPOSIT RATIO (LDR) TERHADAP NON-PERFORMING LOAN DI PT BANK RAKYAT INDONESIA (PERSERO) TbK CABANG WONOGIRI TAHUN 2018
}

\author{
Yuan Sasmita Nugraha, Burhanudin AY, Ratna Damayanti \\ Fakultas Ekonomi Manajemen, Universitas Islam Batik Surakarta \\ Jl. KH. Agus Salim No. 10 Surakarta \\ Korespondensi : yuannugraha99@yahoo.com
}

\begin{abstract}
This study aims to determine the effect of the amount of credit, LAR, and LDR on Non-Performing Loans at PT Bank Rakyat Indonesia (Persero) Tbk Wonogiri. This study used quantitative research methods. The data sources used in this study are secondary data, namely the financial statements of PT Bank Rakyat Indonesia (Persero) Tbk, the Wonogiri Branch Office in 2018. Data collection methods in this research were documentation and literature studies. This study used classical assumption test techniques, multiple linear regression analysis, and hypothesis testing ( $t$ test, $f$ test, coefficient of determination). The results of data analysis are: The amount of credit has a positive and significant affect on the NPL, Loan To Asset Ratio (LAR) has negative and significant affect on the Non-Performing Loan (NPL), Loan To Deposit Ratio (LDR) has positive and significant affect on the NonPerforming Loan (NPL).
\end{abstract}

Keywords: Amount of Credit, LAR, LDR, NPL.

\section{PENDAHULUAN}

Peran perbankan sangat penting, terutama sebagai penggerak pembangunan \& menjaga stabilitas perekonomian suatu negara. Pembangunan ekonomi di suatu negara sangat bergantung kepada dinamika perkembangan dan kontribusi nyata dari sektor perbankan. PT. Bank Rakyat Indonesia (Persero) TBk Cabang Wonogiri dapt membantu program pemerintah dengan jalan penyaluran kredit terhadap masyarakat Wonogiri. Sebagai sebuah lembaga keuangan, PT. Bank Rakyat Indonesia (Persero) TBk Cabang Wonogiri harus memperhatikan aspek-aspek terkait dengan tingkat ketersediaan dana pihak ketiga, penilaian 5C kredit, dan kualitas kredit. Sampai saat ini PT. Bank Rakyat Indonesia (Persero) TBk Cabang Wonogiri tlah mampu menghimpun dana dari masyarakat Wonogiri dan sekitarnya dalam bentuk Giro, Tabungan, dan Deposito. Diketahui bahwa dari tahun 2015-2016 BRI Cabang Wonogiri pertumbuhan dana pihak ketiga meningkat dari Rp. 1,139 Triliyun menjadi Rp. 1,226 Triliyun, meningkat lagi pada Tahun 2017 menjadi Rp. 1,432 Triliyun dan tahun 2018 dana yang dihimpun dari masyarakat mecapai angka 1,664 Triliiyun. Dari sisi kredit, BRI Cabang Wonogiri telah menyalurkan beberapa macam jenis kredit kepada masyaralat Wonogiri dan sekitarnya yaitu KUR, Kredit Mikro Kupedes, 
Kredit Modal Kerja (KMK), Kredit Investasi (KI), dan Kredit Konsumtif. Berdasarkan data internal BRI Cabang Wonogiri, periode tahun 2015 total penyaluran kredit BRI Cabang Wonogiri sebesar Rp 1,087 Triliyun, pada tahun 2016 sebesar Rp 1,321 Triliyun, pada tahun 2017 sebesar Rp 1,488 Triliyun dan pada tahun 2018 sebesar 1,820 Triliyun. Meskipun secara kesluruhan kinerja penyaluran kredit selalu mengalami peningkatan, perlu dicermati mengenai prosentase peningkatan kredit bermasalah yang berada pada kualitas kredit dalam perhatian khusus, kurang lancar, dan macet periode tahun 2015-2018, pada tahun 2015 persentase kredit dalam perhatian khusus sebesar 6.37\% pada tahun 2018 menjadi 29,65\% sementara kredit non performing loan atau macet tahun 2015 sebesar 1,5\% naik di tahun 2018 menjadi 1,88\% dapat diketahui bahwa peningkatan total kredit yang disalurkan setiap tahunnya diikuti oleh peningkatan kredit bermasalah yang disebabkan oleh penurunan kualitas kredit.

Tema tentang bagaimana pengaruh jumlah kredit yang disalurkan, Loan to Asset Ratio, Loan to Deposit Ratio terhadap Non-Performing Loan diambil karena banyaknya jurnal yang membahas tentang kredit dan perbankan dapat menjadi referensi penulis untuk membahas isu tersebut.

\section{LANDASAN TEORI}

\section{Pengertian Bank, Kredit, Non Performing Loan, Loan to asset ratio dan Loan to deposit ratio.}

Bank adalah sebuah lembaga intermediasi keuangan umumnya didirikan dengan kewenangan untuk menerima simpanan uang, meminjamkan uang, dan menerbitkan promes atau yang dikenal sebagai banknote. (Dianti, 2012)

Pengertian bank berdasarkan berdasarkan Undang-Undang Republik Indonesia No. 10 Tahun 1998 tentang perbankan adalah badan usaha yang menghimpun dana dari masyarakat dalam bentuk kredit dan atau bentuk-bentuk lainnya dalam rangka meningkatkan taraf hidup rakyat banyak. Undang-Undang No. 10 Tahun 1998, bank umum adalah bank yang melaksanakan kegiatan usaha secara konvensional berdasarkan prinsip syariah. Kredit adalah penyediaan uang atau tagihan yang dapat dipersamakan dengan itu, berdasarkan persetujuan atau kesepakatan pinjam meminjam.

Menurut Slamet Riyadi (2006) rasio Non -performing loan merupakan perbandingan antara jumlah kredit yang diberikan dengan tingkat kolektibilitas yang merupakan kredit bermasalah dibandingkan dengan total kredit yang diberikan oleh bank.

Loan to Asset Ratio (LAR) adalah rasio yang digunakan untuk mengukur kemampuan bank dalam memenuhi permintaan kredit dengan menggunakan total aset yang dimiliki bank.

$\mathrm{LAR}=\frac{\text { total kredit }}{\text { jumlah asset }} \times 100 \%$ 
Loan to Deposit Ratio merupakan rasio perbandingan antara jumlah dana yang disalurkan ke masyarakat (kredit) dengan jumlah dana masyarakat dan modal sendiri yang digunakan.

$\mathrm{LDR}=\frac{\text { total kredit }}{\text { total dana pihak ketiga }} \times 100 \%$

\section{Kerangka Penelitian}

Untuk mempermudah pemahaman dan memperjelas penelitian maka dapat digambarkan suatu kerangka penelitian teoritis sebagai berikut :

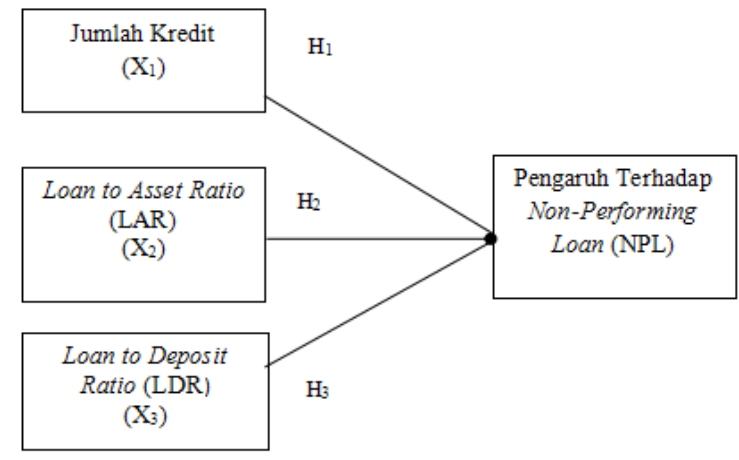

Gambar 1. Kerangka pemikiran

Berdasarkan bagan kerangka pemikiran diatas dapat dijelaskan bahwa variabel dependent disini adalah Non-performing loan. Sedangkan variabel independent yaitu variabel yang mempengaruhi variabel lain. Variabel independent disini adalah jumlah kredit $\left(\mathrm{X}_{1}\right)$, Loan to asset ratio $\left(\mathrm{X}_{2}\right)$ dan Loan to deposit ratio $\left(\mathrm{X}_{3}\right)$

\section{Hipotesa}

1. $\mathrm{H}_{1}=$ Diduga Jumlah Kredit berpengaruh terhadap Non-performing loan

2. $\mathrm{H}_{2}=$ Diduga Loan to Asset Ratio berpengaruh terhadap Non-performing loan

3. $\mathrm{H}_{3}=$ Diduga Loan to Deposit Ratio berpengaruh terhadap Non-performing loan.

\section{METODE PENELITIAN}

\section{Sumber dan Metode Pengumpulan Data}

Jenis data yang digunakan dalam penelitian ini adalah data kuantitatif. Sumber data yang digunakan dalam penelitian ini adalah data sekunder, yaitu data laporan keuangan PT Bank Rakyat Indonesia (Persero) Tbk Kantor Cabang Wonogiri sepanjang tahun 2018 yang telah diaudit oleh auditor internal dari PT Bank Rakyat Indonesia (Persero) Tbk. Dalam penelitian ini, peneliti menggunakan metode dokumentasi dan studi pustaka.

\section{Model, Teknis Analisis dan Pengujian Hipotesis}

Metode yang digunakan dalam penelitian ini adalah kuantitatif, dengan pendekatan deskriptif. Untuk menguji Untuk mengetahui bagaimana pengaruh antara variabel independen (X) dengan variabel dependen (Y). menggunakan analisis regresi linear berganda. Berikut bentuk persamaan regresi dalam penelitian ini: 
$Y=a+b_{1} X_{1}+b_{2} X_{2}+b_{2} X_{3}+e$

Keterangan :

e $\quad=$ error term, diasumsikan 0

$\mathrm{b}_{0} \quad=$ konstanta

$\mathrm{b}_{1}, \mathrm{~b}_{2}, \mathrm{~b}_{3} \quad=$ koefisien regresi

Selanjutnya dilakukan uji t, dan koefisien determinasi.

Untuk menguji hipotesis dilakukan uji t, untuk mengetahui tingkat signifikan kontribusi atau pengaruh variabel bebas yang berpengaruh secara parsial terhadap variabel terikat. Apabila hasil uji t dengan nilai signifikan $<0,05$, berarti variabel secara parsial memiliki pengaruh signifikan terhadap variabel terikat.

\section{HASIL PENELITIAN DAN PEMBAHASAN}

Berdasarkan hipotesis yang disampaikan "Diduga jumlah kredit, Loan to asset ratio dan Loan to deposit ratio berpengaruh terhadap Non-performing loan" terbukti, ditunjukkan dengan hasil analisis regresi linier berganda sebagai berikut:

$\mathrm{Y}=2,014+0,286 \mathrm{X}_{1}+0,084 \mathrm{X}_{2}+0,005 \mathrm{X}_{3}$

Hasil perhitungan menggunakan SPSS 17 didapatkan hasil uji t dan disajikan dalam table berikut:

\begin{tabular}{|l|l|l|l|}
\hline No & Variabel & thitung & Sig. \\
\hline 1 & Jumlah kredit & 2.252 & .007 \\
\hline 2 & LAR & -11.053 & .049 \\
\hline 3 & LDR & 3.171 & 0.25 \\
\hline
\end{tabular}

Tabel 1. Tabel hasil Uji t SPSS

Berdasarkan tabel diatas diperoleh variabel jumlah kredit dengan nilai thitung $=2.252>t_{\text {tabel }}$ $=1.85$, maka $\mathrm{H}_{0}$ ditolak sehingga ada pengaruh positif dan signifikan jumlah kredit terhadap Non-performing loan. Berdasarkan hasil analisis uji t dapat diperoleh variable Loan to asset ratio dengan nilai $\mathrm{t}_{\text {hitung }}=-11.053>\mathrm{t}_{\text {tabel }}=1.85$, maka $\mathrm{H}_{0}$ ditolak sehingga ada pengaruh negatif dan signifikan Loan to asset ratio terhadapNon-performing loan. Berdasarkan hasil analisis uji $\mathrm{t}$ dapat diperoleh variabel Loan to deposit ratio dengan nilai $t_{\text {hitung }}=3.171>\mathrm{t}_{\text {tabel }}$ $=1.85$, maka $\mathrm{H}_{0}$ ditolak sehingga ada pengaruh positif dan signifikan Loan to deposti ratio terhadap Non-performing loan. Hasil analisis deskriptif dan pengujian hipotesis menunjukkan bahwa variabel jumlah kredit, Loan to asset ratio, dan Loan to deposit ratio secara simultan dan parsial berpengaruh signifikan terhadap Non-performing loan. 


\section{KESIMPULAN DAN SARAN}

\section{Kesimpulan}

1) Jumlah kredit terhadap Non-performing loan berpengaruh positif signifikan sehingga semakin tinggi penyaluran kredit maka Non-performing loan semakin meningkat.

2) Loan to asset ratio terhadap Non-performing loan berpengaruh negatif signifikan sehingga semakin naik Loan to asset ratio maka Non-performing loan akan semakin turun.

3) Loan to deposit ratio terhadap Non-performing loan berpengaruh positif signifikan sehingga semakin naik Loan to deposit ratio maka Non-performing loan semakin meningkat.

\section{Saran}

Berdasarkan analisis dan kesimpulan, maka dapat disampaikan saran: Pihak bank harus menyeleksi debitur secara objektif sesuai dengan syarat yang sudah ditentukan. Pihak manajemen bank harus melakukan tindakan untuk menghindari kredit bermasalah. Mengawasi apakah pemberian kredit telah sesuai dengan kebijakan kredit, proses pemberian kredit dan peraturan internal bank. Dengan melihat rasio Non-performing loan perusahaan diharapkan selalu menjaga kualitas kredit yang disalurkan karena naik turunnya Non-performing loan yaitu sebagai salah satu bentuk cerminan kesehatan dari sebuah lembaga perbankan.

\section{DAFTAR PUSTAKA}

Adisaputra, Iksan. 2012. Analisis Faktor-Faktor Yang Mempengaruhi Non Performing Loan Pada PT. Bank Mandiri (Persero) Tbk. Makassar : Skripsi Jurusan Manajemen Fakultas Ekonomi dan Bisnis, Universitas Hasanuddin.

Dianti, Anin. 2012. Analisi Pengaruh Faktor Internal dan Eksternal Terhadap Terjadinya Non-Performing Loan (Studi Kasus pada Bank Umum Konvensional yang Menyediakan Layanan Kredit Pemilikan Rumah Periode 2008-2011). Semarang : Skripsi Jurusan Ekonomi Manajemen Universitas Diponegoro

Ghozali, Imam. 2009. Aplikasi Analisis Multivariated Dengan Program SPSS. Edisi Cetakan IV. Semarang: Badan Penerbit Universitas Diponegoro.

Hasibuan, Malayu S.P. 2008. Manajemen Dasar, Pengertian, dan Masalah, Edisi Revisi. Jakarta: Bumi Aksara.

Kasmir. 2012. Bank dan Lembaga Keuangan Lainnya. Edisi Revisi. Jakarta: PT Raja grafindo Persada

Riyadi, Selamet. 2006. Banking Assets and Liability Management. Edisi ketiga. Jakarta: Penerbit Fakultas Ekonomi Universitas Indonesia 